\title{
Nina Unković
}

\section{Matej Sternen as a Restorer: Selected Examples in Slovenia and Croatia}

Keywords: Matej Sternen, restoration of wall paintings, Celje ceiling, St Michael in Ston, France Stele, Ljubo Karaman

DOI: $10.4312 /$ ars.11.1.204-223

The Slovenian painter, graphic and artist Matej Sternen (September 20, 1870, Verd near Vrhnika - June 28, 1949, Ljubljana) was also known as a restorer who was active not only in Slovenia (from 1898-1941), but also in Dalmatia, Croatia (from 19251935). However, to date his restoration works have only been mentioned in various studies. The purpose of this paper is to present two examples of his restoration activity in Slovenia and Croatia, in order to shed some light on this side of his career.

Sternen attended the School of Applied Arts in Vienna in 1892, and then studied at the Vienna Academy of Fine Arts from 1892 to 1896. In 1898, he started restoration work in Vienna, appointed by the Central Commission, restoring oil and wall paintings. He lived and worked in various places throughout Slovenia, as well as in Munich, and travelled for studies to Italy and Paris.

Sternen's first encounter with an important restoration project was as an assistant of the restorer and painter Alojzij Šubic (1865-1905), working on the wall painting of the church St Lucia in Skaručna (Slovenia), during 1897-1898. For that restoration work the two men received a special award from the Central Commission for the Research and Preservation of Historical Monuments (K. K. Zentralkommission für Denkmalpflege). ${ }^{1}$ Some studies note that the year 1907 was a turning point in Sternen's painting career, when he married his long-time partner Roza Klein, with whom he had already three daughters (Žerovc, 2010, 128). That year he moved to the Kranj region of Slovenia, and thereafter only travelled to foreign countries for short periods of time. Overall, it seems that at this point the artist finally realized that he could not make a living out of painting alone, and thus his restoration work increased steadily in this period. These assumptions are based on his correspondence with France Stele (1886-1972),

1 More information can be found on this website: http://www.slovenska-biografija.si/oseba/ sbi673032/\#slovenski-biografski-leksikon [9. 3. 2017]. 
which show that he started intensive restoration work in Slovenia at this time, which continued until 1915, when he was drafted into the army (Žerovc, 2010, 128).

During the First World War Sternen worked as an illustrator, photographer and restorer, both at the military front and in the hinterland. After the war, he settled in Ljubljana and worked for the Slovenian Monument Office (Spomeniški Urad), which was then led by France Stele. From 1921 onwards, he worked as professor of technical drawing at the Technical Faculty of the University of Ljubljana, and also as a prominent restorer. He often worked on several restoration tasks in different locations at the same time, and the archive data held at the INDOK Centre (Ministry of Culture, Ljubljana), National Gallery in Ljubljana, the Historic Archive in Celje, and the Conservation Department of the Ministry of Culture in Croatia, shows that, on the majority of occasions, he was the only person conducting these restoration projects.

As a restorer, Sternen was a skilled copyist and innovator of various techniques for use with wall paintings. He also had extensive restoration experience with artefacts from all historical periods from the High Middle Ages and after (Smrekar, 2004, 109). His reputation as a restorer improved markedly after his work on the wall paintings in the church of St Primož in Kamnik in 1911. Another important year was 1914, when Sternen was a candidate for the position of official restorer in Vienna. Unfortunately, he was not selected due to the already large number of advisors in the region, although his work was highly praised (Informacijsko-dokumentacijski center za dediščino, Ministrstvo za kulturo RS, 1914/406). In the southern region of Croatia (Dalmatia), Sternen restored paintings and wall paintings in Šibenik, Trogir, Split, Ston and the islands of Rab and Hvar and, in the period from 1925-1938 (Unković, 2011, 270). During all this restoration work that he was conducting in Slovenia and Dalmatia, he was also producing new art works. Overall, he managed to produce 54 artworks during his intensive restoration work in Slovenia and Dalmatia from 1919-1939, some even inspired by the landscape of the Croatian coast where he was conducting his restoration projects, such as Rab (1921), Dalmatinka (1926), Dubrovnik, Pristaničče v Dubrovniku, Morska obala, (1930) (Ilich-Klančnik, 1974, 118).

Sternen thus did not give up his painting, while also making sketches that resonated with shades of green, blue and pale yellow (Ilich-Klančnik, 1974, 50). In the years 1926-1927, however, he changed his coloristic preferences, using mostly black as a background and gradually building the images with bright shades of orange, red and yellow. For example, in those years he painted: Violinistka $v$ dolgi beli obleki s tančico (1925), Pred zrcalom (1926), Dekle s knjigo (1927) and Maska (1927). The paintings from the period between two World Wars (1919-1939) were a sign of mature expression embroidered with youthful energy and the joy of experimentation 
(Ilich-Klančnik, 1974, 118). Sternen not only painted oil on canvas, but also produced graphics and portable frescos.

\section{Collaboration with France Stele and Liubo Karaman}

Sternen's collaboration with France Stele started in 1910, while thelatter was preparing his thesis on Gothic wall paintings in Carniola. Stele considered Sternen his first and only associate, and remained in close contact with him until death (Černigoj, 1965-66, 22). He developed respect for Sternen's abilities when Max Dvořák ${ }^{2}$ recommended that he visit St Primož above Kamnik, where the then-honorary Slovene conservator Ivan Franke (1841-1927) came into conflict with Sternen regarding the restoration of the wall painting in the local church. Franke had a very strict interpretation of the principle "conserve do not restore", ${ }^{3}$ and demanded that Sternen glue the new, badly done overlays in tempera rather than remove them, even though the original layer was still very well preserved. Sternen refused to follow the conservator's command, and instead chose to present the original layer while keeping the later overlays only on the parts where the original layer was not preserved (Černigoj, 1965-66, 22).

The stereotype of restorers being unfulfilled artists, even dilettantes, was thus disproved at the very start of Sternen's career. Indeed, although this prejudice is unfortunately not without an element of truth, Stele set new standards in restoration when selecting his associates, finding the very best candidate in Sternen. In contrast to paintings, however, the situation was not so good with regard to sculptors working on restoration projects, since the decline of many noted $19^{\text {th }}$-century workshops meant that much of the needed expertise was now being lost (Stepančič, 2014, 97). Interestingly, Stele noted in 1944, in the catalogue for Sternen's exhibition of portraits, the fact that many people who knew the man as a restorer were unfamiliar with his rich opus as a painter (Žerovc, 2010, 128).

2 The Czech art historian and conservator, Max Dvořák (1874-1921), made substantial contributions to the field of conservation; after the death of Alois Riegl, he took over his position as director of the Central Commission for the Preservation of Artistic and Historical Monuments. From this position, he continued teaching and developing ground-breaking work in conservation policy and practice, including the publication of the Commission's Yearbook (Kunstgeschichtliches Jahrbuch der Zentralkommission für die Erhaltung der Kunst- und historischen Denkmale) and the launching in 1907 of a series of publications - Österreichische Kunsttopographie - that aimed to build an inventory of the entire corpus of existing works of art and architecture in Austria-Hungary.

3 Georg Dehio, Alois Riegl, and Max Dvořák advocated respect for all the elements of a monument. Through their work, monument protection reached a level in which historical authenticity became the standard practice. Dehio interpreted the slogan "conserve, do not restore" as meaning "conservation techniques are the only true method of monument preservation" (Dehio, 1905). Alois Riegl's 1903 book Der moderne Denkmalkultus (The Modern Cult of Monuments) played a key role in monument protection, since it defined a system of monument-protection values that respected all the elements of a monument. 
In 1920, Ljubo Karaman (1886-1971), then assistant conservator of the Conservation Office for Dalmatia in Split, was informed by France Stele about the state of conservation work in Slovenia, and the successful collaborations that had occurred with Matej Sternen. After being convinced of Sternen's capabilities as a restorer, now with over 25 years of experience guided by the most modern principles of monument preservation, the Conservation Office in Dalmatia signed a contract of collaboration with him. Sternen's seriousness and devotion to the tasks he was assigned resulted in a period of successful cooperation with this office that lasted from 1925 until 1932. During that time, Karaman and Sternen visited numerous ecclesiastical and private collections, determining their priorities for the restoration of artworks, with a focus on those by local masters from the areas of Šibenik, Trogir, Split, Hvar, Korčula, Ston, and Dubrovnik (Unković, 2011, 272). Most of the related artworks were sent to Slovenia, while those that were less damaged were restored in situ, and this may be considered the beginning of this practice in this region. During this time, Sternen restored not only panel paintings, but also wall paintings (such as in Ston and Trogir).

We will now take a closer look at the two examples of Matej Sternen's restoration work: the restoration of the paintings decorating the ceiling of the Old Manor House in Celje (1926-1927), and that of the wall paintings in the church of St Michael near Ston (in the southern region of Croatia) (1926-1928).

\section{Restoration of the "Celje ceiling" (1926-1927)}

\section{Description of the paintings and their supposed origin}

The paintings decorating the ceiling in the central hall of the Old Manor House in Celje, which is home to the permanent exhibition of the Regional Museum, are one of the main attractions of the institution. Known as a rare example of profane painting from the Renaissance to the early Baroque period, the ceiling's 142.6 square meters are decorated with eleven paintings in the technique of tempera on canvas. They present the following scenes: A Battle between the Latins and Trojans, The Death of Camilla, The Fall of Icarus, Ixion's Punishment, The Fall of Phaeton, The Torment of Tantalus, and Spring, Summer, Autumn and Winter. These images are arranged in such a way that they give the central image the illusion of an architectural structure, with towers and the final edge in the shape of a cross, which surrounds an expanse of open sky. Around this are balustrade railings with carpets hanging over them, and behind these are depicted noblemen, courtiers, soldiers and the supposed client, Thurn, as well as a self-portrait of the painter and his assistant. Along the longer sides of the central field are the figures of Jupiter and Neptune. The longer sides of the ceiling contain 
allegorical images of the four seasons showing everyday tasks, and the shorter sides show a battle from the war between the Latins and Trojans and the death of Camilla. The corners are filled with figures of four giants (depicting Icarus, Ixion, Phaeton and Tantalus).

Many scholars and researchers have written about the ceiling's provenance and influences with regard to both execution and technique, such as France Stele, Ivan Stopar, Stanislav Szymansky, Jože Curk, Janko Orožen, Emilijan Cevc, Gabrijela Kovačič and Daša Pahor (Stele, 1929; Szyimanski, 1973-74, 215-229; Stopar, 2002, 60; Cevc, 2002, 9-30, Pahor, 2008, 207-232; Kovačič, 2016). ${ }^{4}$ Remarkably, the creator of the "Celje ceiling" remains a mystery. Some experts are of the opinion that it must have been an Italian master, and possibly someone who had spent time in Celje. France Stele saw possible influences from two sources: the northern Italian trompe loeil paintings, and Flemish art, particularly that from the circle of the graphic artist and painter Vredeman de Vries (Stele, 1929). Emilijan Cevc saw the ceiling as being influenced by the work of the Bologna master Pellegrino Thibaldi (Cevc, 2002, 9). On the other side, Daša Pahor, in her work from 2008, elaborated the possibility that the author could have been influenced by, or was even part of, the circle of painters who worked for the court of Rudolf II in Prague (Pahor, 2008, 218). Regardless of his identity, the artist was clearly a master of perspective, and the ceiling remains one of the most remarkable works of art in Slovenia.

\section{The discovery of the ceiling (1926)}

The Old Manor House was built from 1581-1595 upon the order of Count Jobst Thurn-Valsassina, with some additions made until 1660 by an unknown Italian architect from the so-called Graz School of architects, founded by Domenico dell'Allio. Later, the Thurn-Valsassina family decided to live in Graz most of the time, so the building began to decay, and in 1831 it was offered for purchase. The Municipality of Celje thus bought the Old Manor House, and in 1874 they established an elementary school on the premises. From 1905 to 1945, the building was used by the Celje District Court (Kovačič, 2016) .

The Old Manor House was damaged twice - once by fire, in January 1926, and later during the Second World War, although fortunately the central part was not affected. During the first restoration project that began in 1926, although the Celje District Court still did not own all of the complex, it nevertheless started the process

4 More information can be found on the website: http://www.kamra.si/sl/digitalne-zbirke/item/celjskistrop-evropska-mojstrovina-2.html [1.3. 2017].

5 More information can be found on the website: http://www.kamra.si/sl/digitalne-zbirke/item/celjskistrop-evropska-mojstrovina-2.html [01. 3. 2017]. 
of recovery, asking for assistance from the Local Magistrate to also address some of the previous superficial repairs to the structure (Zgodovinski arhiv Celje, Ministrstvo za kulturo RS, SI_ZAC/0024/002/006/00032/15-26-2).

In May 1926, France Stele, upon answering the call of the Local Magistrate, examined the state of the complex with Matej Sternen, and found that underneath the ruined wooden ceiling lay the original one, with paintings from the $17^{\text {th }}$ century. The paintings were thus saved thanks to the later wooden panel, which was probably added during the late $19^{\text {th }}$ century, when the Old Manor House was used as an elementary school. After its discovery, the "Celje ceiling" was hailed as the only example of its kind in the southern Alps, especially after the irreparable damage that occurred in the Second World War to many of Europe's artworks and monuments.

In June 1926, Stele wrote a detailed proposal for the conservation of the façade, fences, terrace and interior of the Old Manor House (Zgodovinski arhiv Celje, Ministrstvo za kulturo RS, SI_ZAC/0024/002/006/00032/15-26-2-11). The proposal was accepted by 19 members of the Commission named by the Local Magistrate (Zgodovinski arhiv Celje, Ministrstvo za kulturo RS, SI_ZAC/0024/002/006/00032/23). The move was also supported by Ivan Zorman (then director of the National Gallery in Ljubljana) and the architect Vladimir Šubic (1894-1946), who made plans for the renovation of the staircases (Zgodovinski arhiv Celje, Ministrstvo za kulturo RS, SI_ ZAC/0024/002/006/00032/15-26-2-12).

Before the restoration work began, Sternen described the state of the paintings and proposed a plan that would cost 50,000 dinars, with the project including photography of the state of the paintings, lining the paintings on new canvases, patching the damaged parts of the canvases, cleaning and applying a ground layer to the damaged parts (gesso grunding), and then retouching and technical sketching of the ceiling after the restoration treatment (the details of which were later published in Stele's Celjski strop from 1929). In his description of the state of the paintings, Sternen emphasized that the canvases were pierced and broken in several places, and found traces of previous restoration interventions, a fact which raised further questions about previous undocumented work on the ceiling (Zgodovinski arhiv Celje, SI_ ZAC/0024/002/006/00032/3). The central painting was in a more well-preserved state than the side ones, and Sternen concluded that the damage was mostly due to leaks from the roof, which caused severe deterioration to the corners showing the figures of the giants, with additional damage being due to fire. These leaks caused the loosening of the adhesive between the binder and pigments, and consequently some parts were almost unrecognizable (Zgodovinski arhiv Celje, Ministrstvo za kulturo RS, SI_ZAC/0024/002/006/00032). 


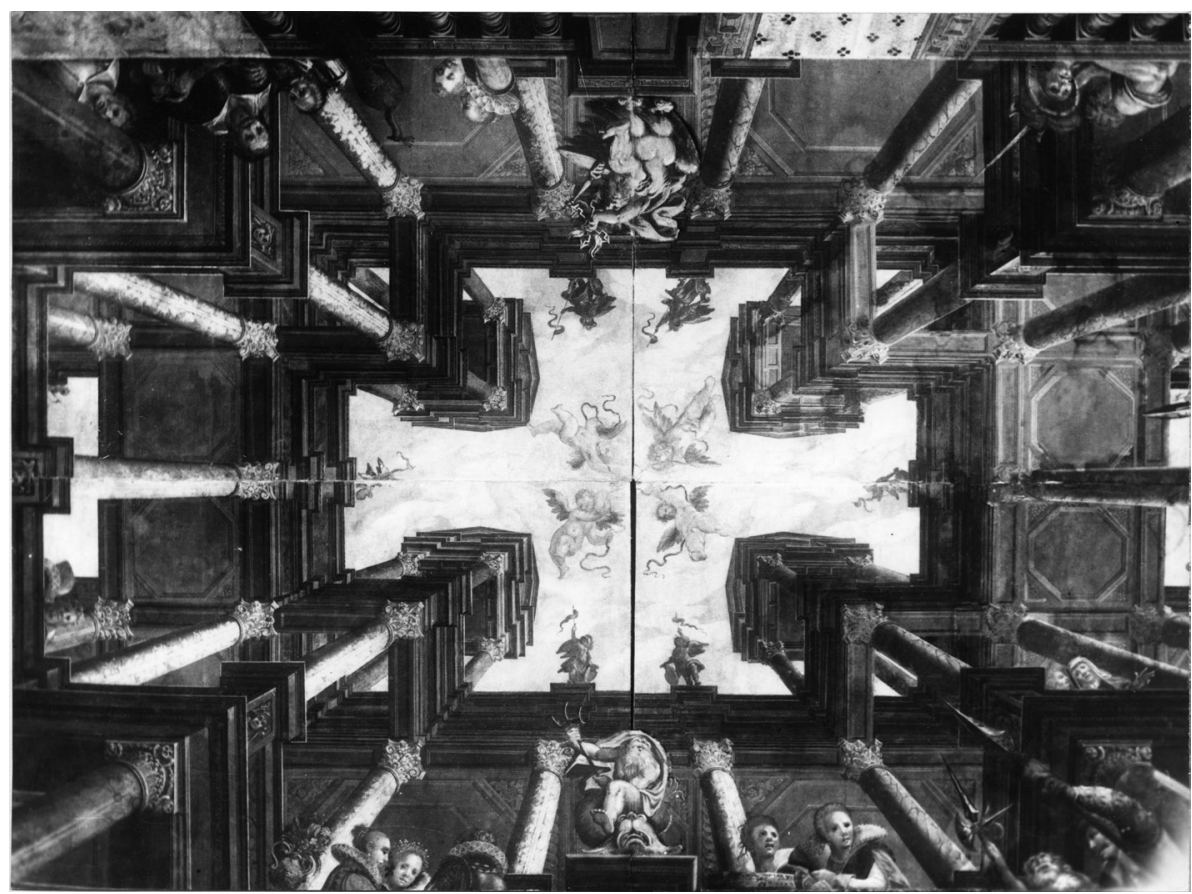

Fig. 1: Celje, central painting of the Old Manor House ceiling during the restoration treatment, 1926-1927 (Informacijsko-dokumentacijski center za dediščino, Ministrstvo za kulturo RS).

\section{Restoration of the paintings and frames}

While Sternen was examining the state of the paintings with Stele in July 1926, he made a test with adhesive to glue the falling paint layers, concluding that a thorough restoration was essential. After the project proposal was approved and the paintings dismantled, the restoration treatments began in October 1926, and lasted for one year. Due to the poor state of some of the paintings it was decided that they should not be transported to Ljubljana, and that the restoration work should be conducted in the small hall of the Celje Old Manor House (Zgodovinski arhiv Celje, Ministrstvo za kulturo RS, SI_ZAC/0024/002/006/00032/MOC 1918-1941, 42/B2_6631/27).

Before Sternen started this project he was still working on the restoration of paintings in the Franciscan monastery in the town of Hvar (poliptich by Francesco Santa Croce, 1583) (Arhiv: Konzervatorski zavod, Odjel u Splitu, Ministarstvo RH, 1926/45). It is remarkable that Sternen was engaged in so many restoration projects at the same time in two different countries, but it should be noted that the archives show he had four assistants for the restoration of the "Celje ceiling" (Zgodovinski arhiv 
Celje, Ministrstvo za kulturo RS, SI_ZAC/0024/002/006/00032/18). Two of these, Miloš Hohnjec and Mihael Vrenko, worked on repairing the wooden frames from December 1926 until October 1927 (Zgodovinski arhiv Celje, Ministrstvo za kulturo RS, SI_ZAC/0024/002/006/00032/780-27). Miloš Hohnjec, a sculptor and gilder from Celje, cleaned the frames with his assistants, reconstructed missing and severely damaged parts (using wood veneer from Vienna), glued and strengthened areas where needed, consolidated the wood with shellac, protected the friezes with a layer of alaum coated with ethanol, retouched the original parts using tempera, gilded the frames, added a gesso layer and retouched the new parts, as well as reconstructing and gilding four vases (ornaments which connect the frames). ${ }^{6}$

One interesting fact that Sternen mentioned in his project proposal was that some parts of the paintings had already been restored, such as The Death of Camilla and the middle of the central paintings. Before the restoration treatment, all the paintings were covered with thick layers of dirt, and some parts were even burnt to such an extent that it was not possible to distinguish what they represented. During the treatment, Sternen concluded that the paintings were made using the tempera, and thus should not be cleaned with any substances that contained water. The paintings The Battle between the Latins and Trojans and The Fall of Tantalus were the most damaged. With regard to the first, the canvas was especially damaged on the righthand side, and the painted layer was unstable and easily peeled off.

All the paintings suffered from mould, which covered the majority of their surfaces, and this the cleaning process a challenge for Sternen. Unfortunately, he did not describe which materials and techniques he used for this phase. He also decided that all the paintings should be lined on new, stronger canvases, using a starch paste composed of beeswax with turpentine oil, resin and alum powder. The wax along with all the other components was put on the back of the original paintings and on the new canvases, and treated with heat and pressure until the canvases were glued, being left to dry for a few days after that. This also achieved the consolidation of the painted layers. Damaged parts with missing ground layers were prepared with a substrate layer of gesso (a compound of chalk, gypsum and hot hide glue adhesive). The next phase was to retouch the new parts with tempera emulsion. The type of emulsion that was used was not described, but due the high humidity and damp of the ceiling, and according to his previous guidelines with regard to not using any water-based materials, we can conclude that Sternen used casein-oil-resin emulsion (casein tempera, stand oil and damar varnish), which is very resistant to extreme changes in humidity.

6 In his project proposal, Hohnjec terms these "wooden vases." There are four of these vases in the shapes of pine cones and acanthus leaves. To date, researchers have found no similar vases in any other locations. 


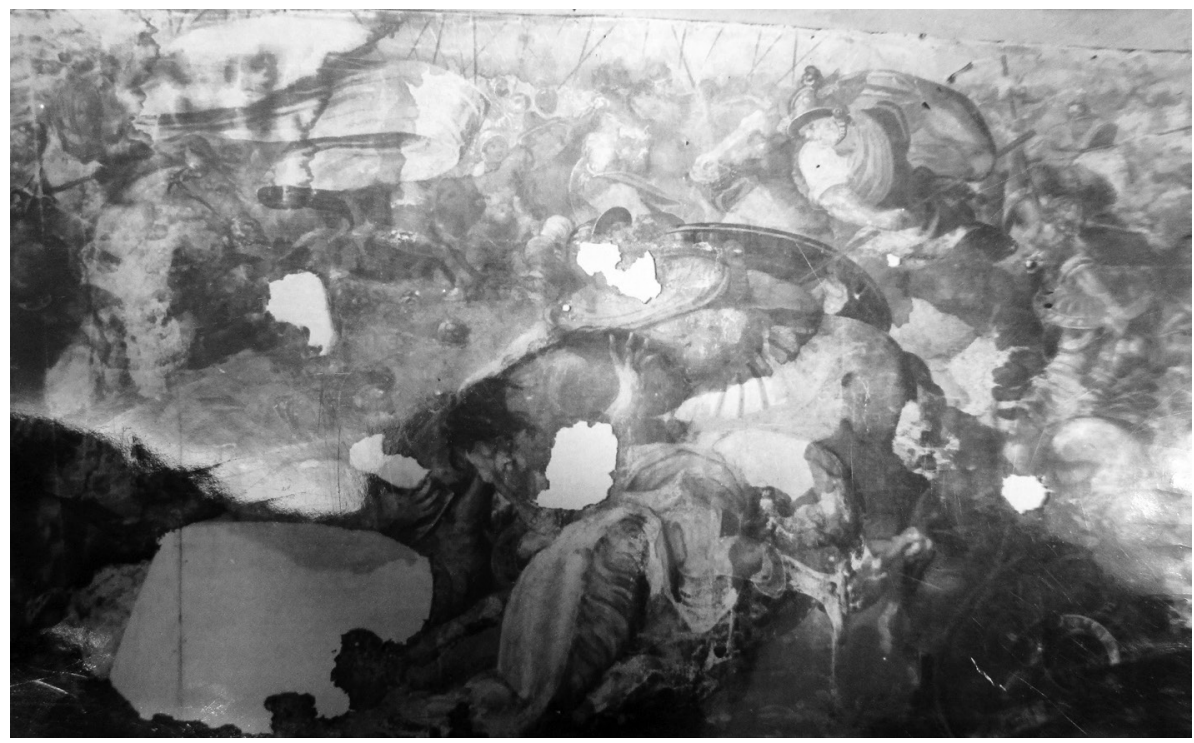

Fig. 2a: Celje, Old Manor House ceiling, The Battle between the Latins and Trojans, before restoration, 1926 (Informacijsko-dokumentacijski center za dediščino, Ministrstvo za kulturo RS).

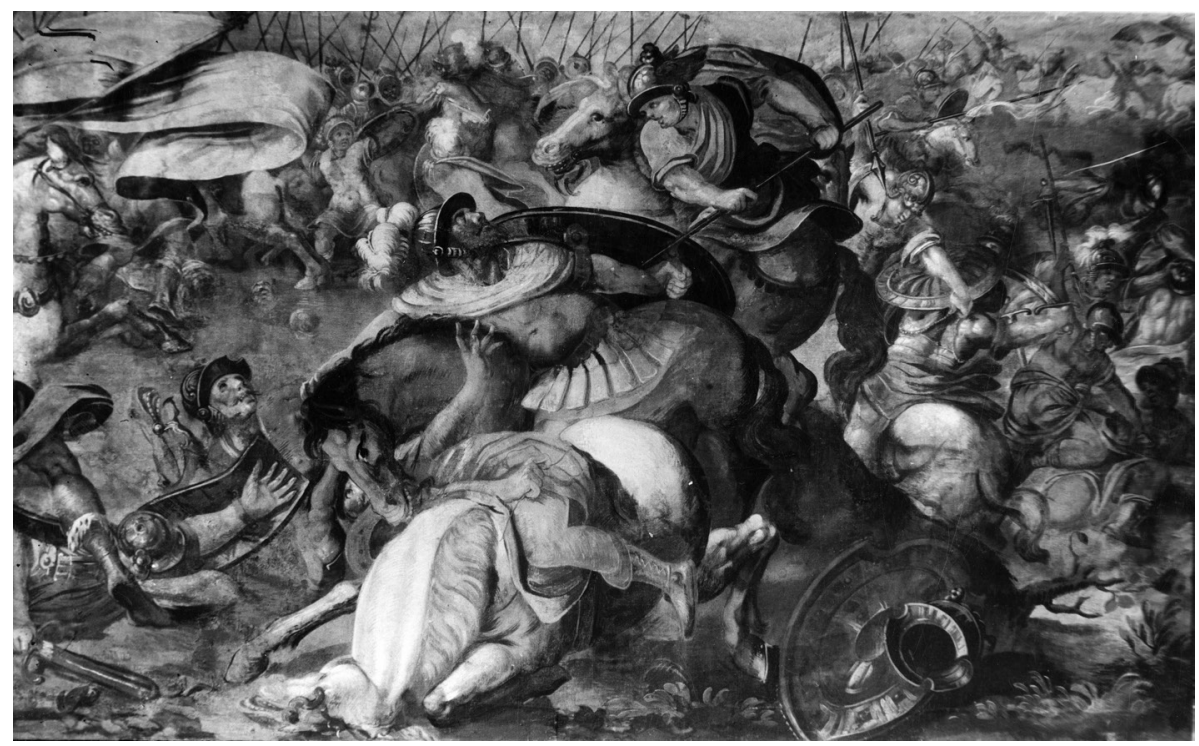

Fig. 2b: Celje, Old Manor House ceiling, The Battle between the Latins and Trojans, after restoration, 1927 (Informacijsko-dokumentacijski center za dediščino, Ministrstvo za kulturo RS) With regard to The Fall of Tantalus, the left part of the painted layer was burned, and thus had to be thoroughly cleaned and retouched. 


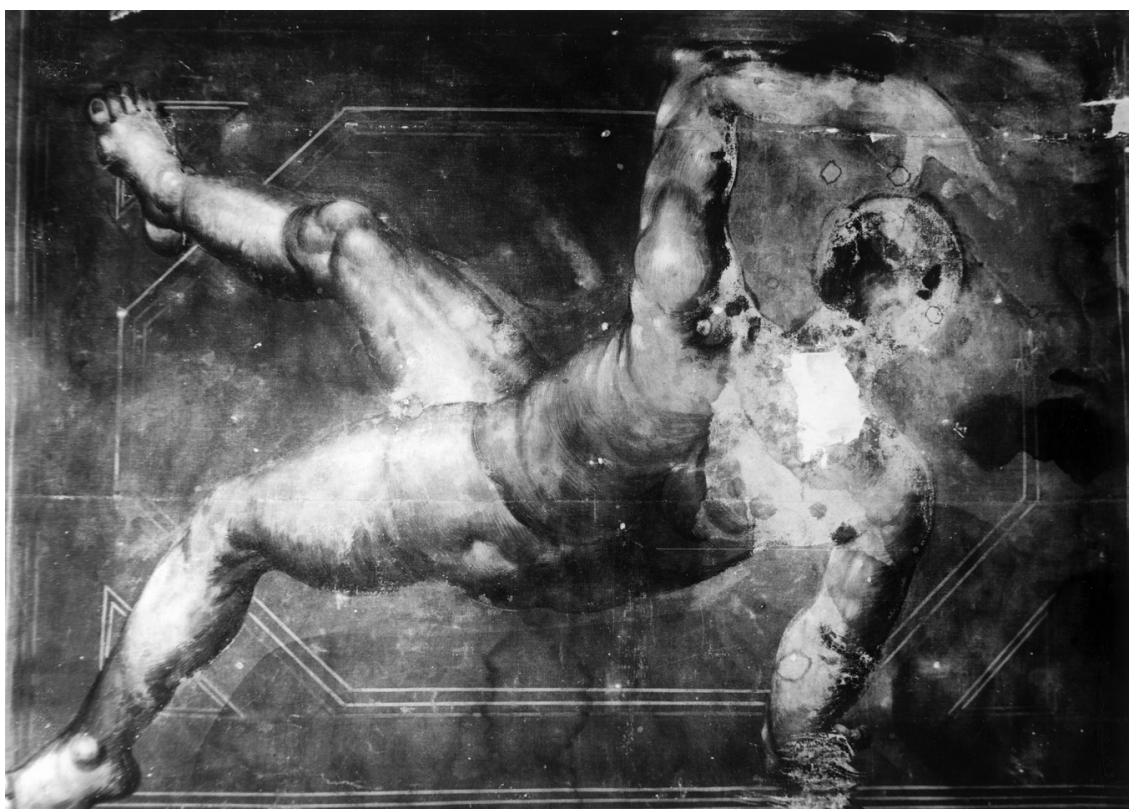

Fig. 3a: Celje, Old Manor House ceiling, The Fall of Tantalus, before restoration, 1926 (Informacijsko-dokumentacijski center za dediščino, Ministrstvo za kulturo RS).

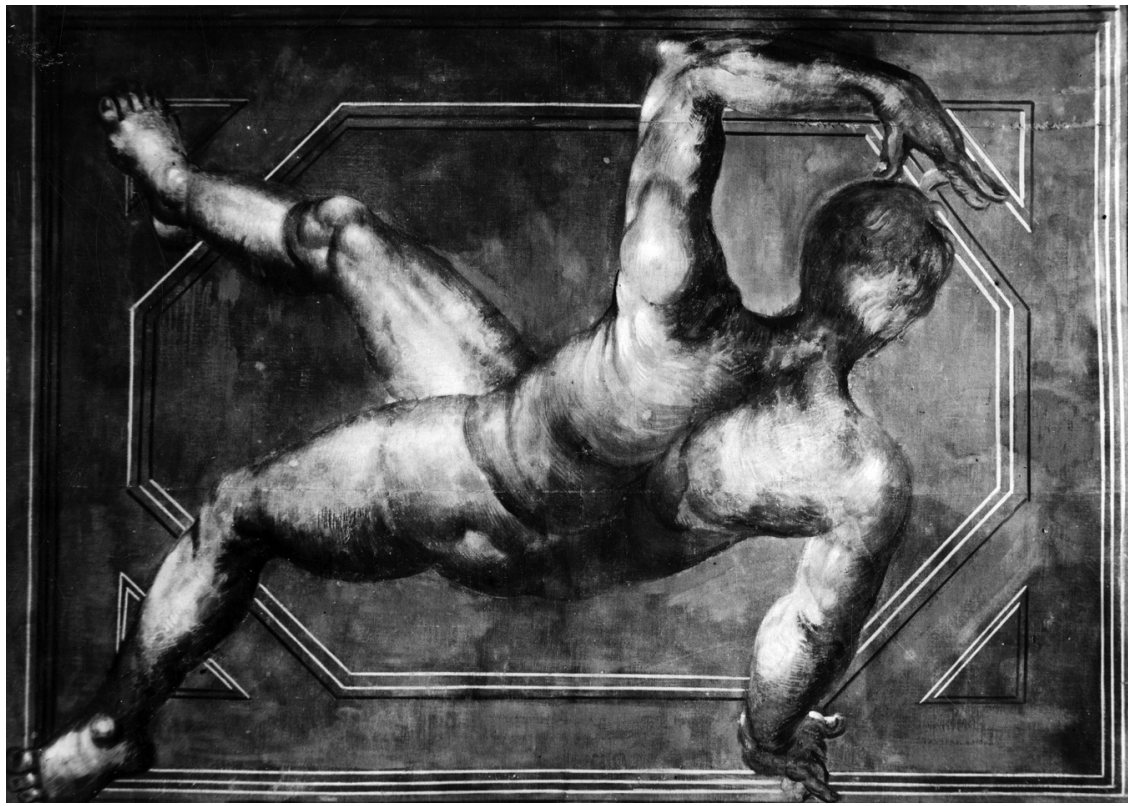

Fig. 3b: Celje, Old Manor House ceiling, The Fall of Tantalus, after restoration, 1927 (Informacijsko-dokumentacijski center za dediščino, Ministrstvo za kulturo RS). 
A more detailed description of the restoration work carried out on this project is not preserved in the archives, except for a mention of Stele's decision to glue the central painting on a wooden panel to make it more stable, due to its large dimensions. Stele also recommended protecting the paint layer with a coating of shellac. The restoration of the paintings was concluded on the $29^{\text {th }}$ of November 1927 , and cost a total of 79,570 dinars, 19,000 over the original budget. An interesting fact is that the restoration work was subsequently revised at the request of the Local Magistrate by Ivan Zorman (18891969), France Mesesnel (1889-1969) and Jože Plečnik (1872-1957), with all agreeing that the restoration made by Sternen had been of a very high quality (Zgodovinski arhiv Celje, Ministrstvo za kulturo RS, SI_ZAC/0024/002/006/00032).

The technical decisions that Sternen made in this restoration project are probably why the "Celje ceiling" has been preserved for so many years. During a visual examination of the retouched elements on the ceiling, Sternen's pictorial expression is especially clear in the impasto layering technique. Moreover, Sternen's documentation represents invaluable information about the previous state of the paintings and the technology and techniques he applies, which will prove useful for the next round of restoration treatment, planned for the years 2017-2018. ${ }^{7}$ The Regional Museum of Celje and the Restoration Center in Ljubljana started to examine the ceiling in 2015 , due to rapid decay caused mostly by mould. ${ }^{8}$ This started as a project with the aim of protecting the ceiling, but also with the foal of investigating the original techniques and determining the restored elements. To date, samples of mould specimens have been investigated, measurements of the variations in microclimate in the space have been carried out, sampling techniques have been applied to reveal the binders, pigments and coatings used (both in the original and during the restoration treatment), and thermographic recordings of the ceiling have been performed. ${ }^{9}$

The Regional Museum in Celje has also organized two exhibitions (in 2016 and 2017) ${ }^{10}$ with the objective of presenting the historical importance of the ceiling and the need for its restoration, which is scheduled to begin after the results of the measurements and analysis have been obtained.

7 More information can be found on the websites: http://www.antenastajerska.si/7909,

http://tatrenutek.si/kultura/celjski-strop-iz-stare-grofije-se-vedno-caka-na-obnovo, http://www.zvkds.si/sl/clanek/celje-celjski-strop.

8 The project is lead by Gabrijela Kovačič, art historian and curator, (Regional Museum of Celje).

9 Conversation with Gabrijela Kovačič (art historian, curator, Regional Museum Celje) in Celje, 14. 4. 2017.

10 Celjski strop, evropska majstorovina, Celje, 21. 5. 2015. Uganke Celjskega stropa, Celje, 20. 4. 2017. 


\section{Restoration of the wall paintings in St Michael Church in Ston (1926-1928)}

As stated in the introduction to this paper, one of the most outstanding aspects of Sternen's restoration work was his ability to conduct several projects in parallel. At roughly same time as the restoration of "Celje ceiling," he was working on another major project, the wall painting of the Church St Michael in Ston. This example is highlighted to briefly present Sternen's approach to restoration of wall paintings.

\section{Description of St Michael's Church}

The Church of St Michael in Ston is an important example of medieval architecture in the wider Dubrovnik area, and the only confirmed example of a southern Dalmatian single nave domed building in the region (Fisković, 1965; Gabelić, 1991, 27-29). It was built on top of Gradac Hill, previously called the Hill of St Michael, on the site of an earlier fortification (Zaninović, 1970, 489-502; Lupis, 2000, 57). It had the function of a royal chapel for the nearby fortified castle of the Zachlumian knights. ${ }^{11}$ A Dominican monastery complex was built next to St Michael's Church in the $16^{\text {th }}$ century, housing Roman Catholic tertiary nuns. St. Michael's is a single nave church, oriented west/east and with an apse. The interior of the church is divided into sections by arches, lesenes and niches, with the remaining fresco paintings dating back to the $11^{\text {th }}$ century. This early Romanesque cycle of frescoes is attributed to an artist or artists working under the influence of a Southern Italian Benedictine painting school (Fisković, 1960, 48-49).

The Church of St Michael was thoroughly examined by Ljubo Karaman in 1921 (Arhiv, Konzervatorski zavod, Odjel u Splitu, Ministarstvo RH, 1928/58). During a fiveyear period of research it was decided to examine the wall painting inside the building with the help of Matej Sternen (1926-1928), which resulted in a book that was published in 1928 (Karaman, 1928, 81-116). The outstanding results of Sternen's work were so important that Karaman continued to publish new comparisons and theses in the following years on the figure of the church's donor, St Michael (Mihajlo), who wore the same crown as the Croatian King on the relief in the baptistery from Split (today kept in the Temple of Jupiter), also made in the $11^{\text {th }}$ century (Karaman, 1925, 391-412).

Many studies have been written about Ston's wall paintings, confirming the dating of the church to the $11^{\text {th }}$ century, and associating it with the Doclean (Zachlumian) ruler Mihajlo Vojislavljevic (cca 1051-1081) (Karaman, 1925, 391-412). However,

11 Zahumlje, also called Hum, was a medieval principality located in the modern-day regions of Herzegovina and southern Dalmatia. 
newer research considers that the wall paintings were made before this, given the stylized linearism of the figures and ornaments, which seem completely abstracted and have almost geometrical forms (Tomas, 2016, 49).

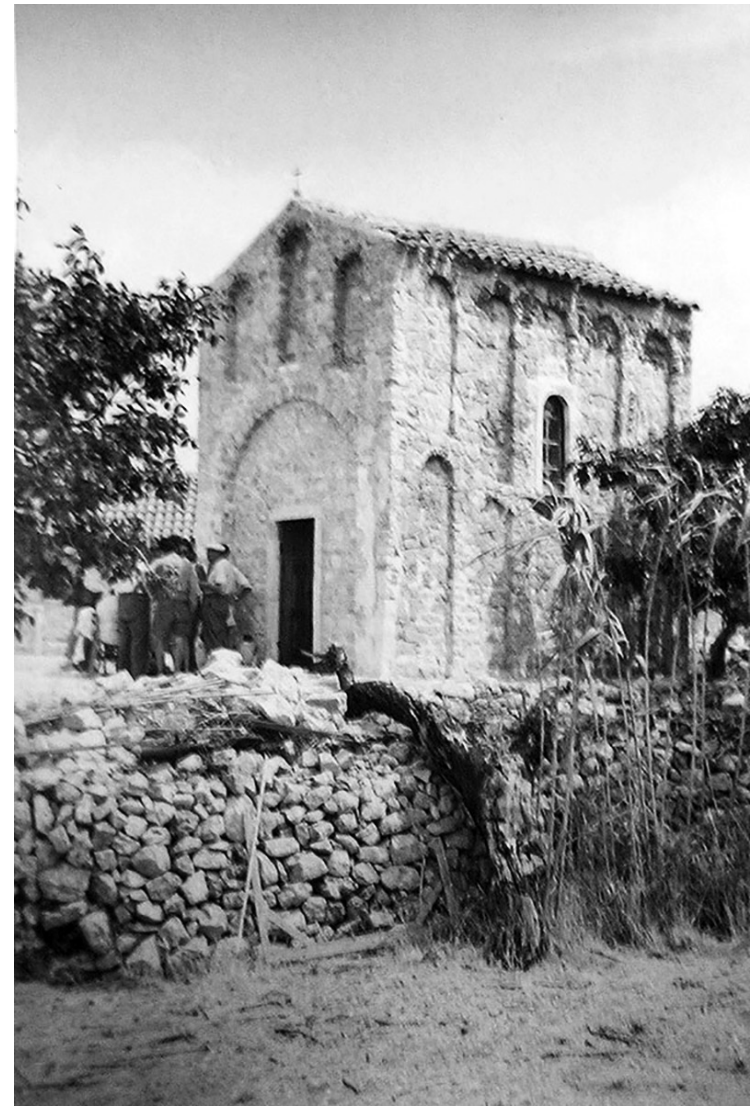

Fig. 4: Ston, Church of St Michael, before restoration, 1921 (Konzervatorski zavod, Odjel u Splitu, Ministarstvo RH).

Plans for the conservation works and the related discoveries

Working as an art historian, Karaman was very intrigued by the church due to its interesting design and construction, the walled fragments and braid sculpture, and by the remains of the wall painting showing the donor. During his first visit in 1921, Karaman described the damage to the church, emphasizing the loose and wide cracks in the walls, and expressing concern that even a mild earthquake could further damage the murals. The wall paintings were also damaged due to humidity and exposure to the rain, with water able to come through to the interior of the building due to the damaged walls. Karaman thus immediately began to look for 
financial support to enable conservation work, although at that time this was very difficult to obtain.

The conservation plan for the church was based on the following actions:

- making architectural graphical drawings of the state of the church (by the architect Valenta, from Dubrovnik), with both layout sections and ground plans,

- making a drawing of the donor, St Michael (by the Dubrovnik painter and high school professor Frano Rasic),

- carrying out examinations of the wall paintings (by Matej Sternen in 1926).

The wall paintings in the Church of St Michael in Ston date back to the last quarter of the $11^{\text {th }}$ century, and are among the oldest murals in Dalmatia. Although substantial parts were covered with plaster and lime coating in the late $19^{\text {th }}$ century, Karaman, along with Sternen, discovered the wall paintings in 1926 (Štrkalj, 1989;12 Srša, 2010, 11-30). Among the fragments that survived, certainly the most impressive is the figure of the donor in the western niche on the north wall, and the figures of St George in the opposite niche, along with the evangelists, saints and angels who lead sinners before the final judgment.

Sternen, after examining the state of the building, concluded that the restoration work would be especially difficult and complex, because the church was in a state of decay, and therefore recommended to the conservators that they first work to rehabilitate the church (Arhiv, Konzervatorski zavod, Odjel u Splitu, Ministarstvo RH, 1926/53). Sternen's suggestion was adopted by Karaman, and was in agreement with the current Jurisdiction for the Monuments. In June 1928, the Conservation Office thus began the preliminary actions for the church's rehabilitation. These works included giving the church a new roof, construction of a ground-level entrance and rehabilitation of the window opening near the altars. However, the work faced delays due to problems with the correction and conservation of the complex ornaments eventually leaving the conservators without enough funds to finish the project. As such, the restoration work of Matej Sternen had to be started later than expected, in September 1928. The remaining archive data reveals that before the restoration work started Sternen had noticed the high quality of the under-paint drawing and original colours. The wall paintings had never been cared for by a professional conservator or restorer, but instead only by amateurs who had covered the work with plaster. Sternen not only wanted to remove the plaster, but also to clean the wall paintings and photograph them.

12 Unpublished, the pages are not numbered. 


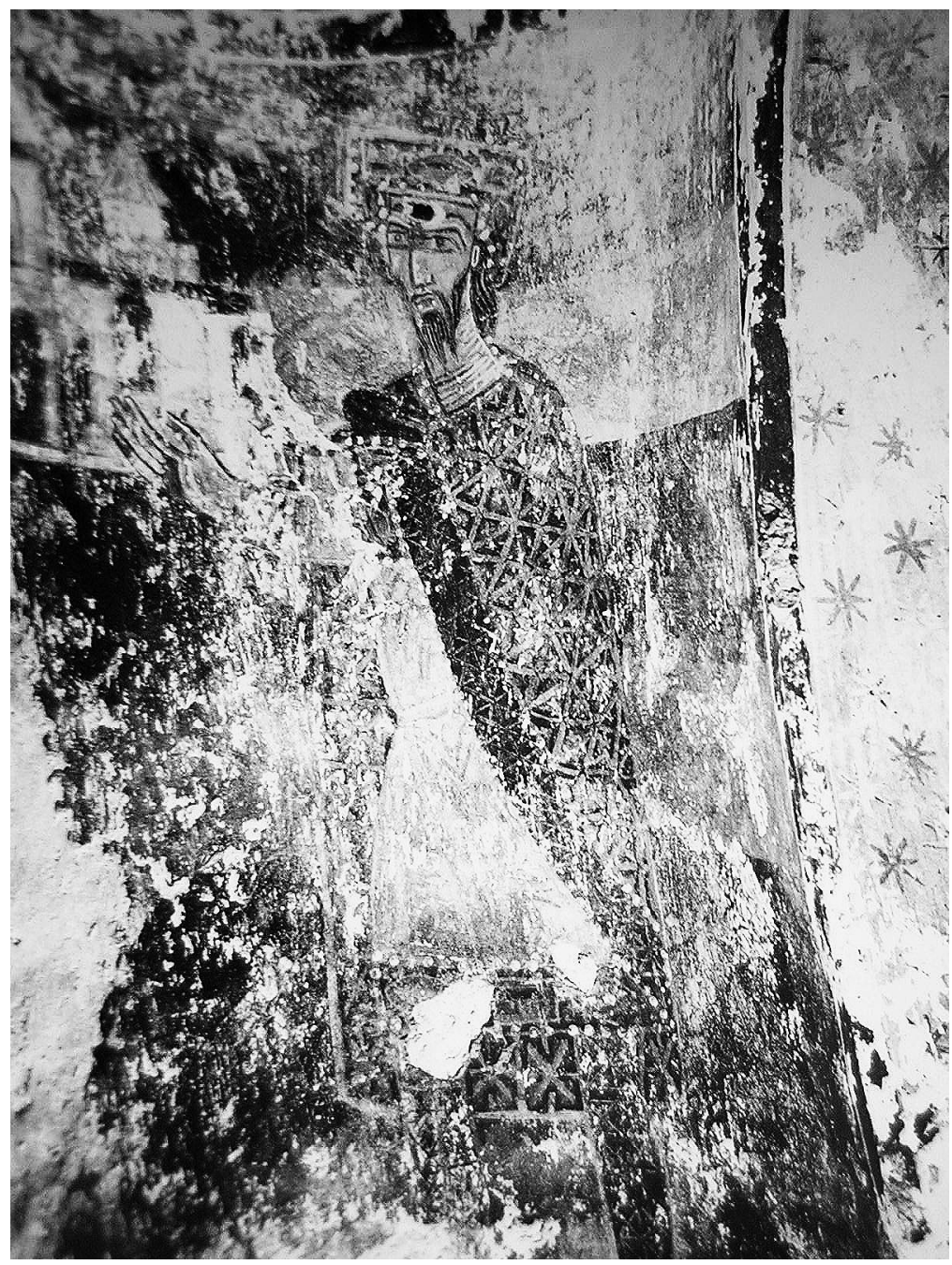

Figure 5: Ston, Church of St Michael, detail of the wall painting during the restoration treatment, 1928

(Konzervatorski zavod, Odjel u Splitu, Ministarstvo RH).

Sternen documented that the lime plaster was difficult to remove, and thus the work could not be finished as planned. Complications that arose in the process of the conservation treatment required additional funding that the conservators in Split and Dubrovnik could not deliver, and so the process had to be stopped for a year. In the meantime, Ljubo Karaman secured alternative funding from the Archaeological Society in Split, named "Bihac," and thus the work could be resumed. Sternen then discovered fragments of wall paintings while making a layout drawing 
of the church's wall paintings, which helped future researchers to know the exact positions of the paintings.

After the completion of the restoration work, Sternen informed Karaman that he had discovered a fragment of St Michael, who in his right hand holds a sword while in his left is a shield, revealing a fragment of the inscription ... GIVS GEORGIUS. Sternen also found another fresco on the same side of the church depicting St John the Baptist, and on the left side he discovered that some smaller fragments had been removed. Sternen was the person who revealed the presentation of the donor, based on a technical analysis that dated the production of the wall paintings (cca 700-800). After Sternen's departure from the project, Karaman continued the repair work on the church. The issue of lack of funds was addressed with a loan of 10,000 dinars from the Ministry of Education in Belgrade, which he transferred to the Building Section of Dubrovnik, the institution that later led the supervision of the conservation work, particularly regarding the maintenance of the existing wall paintings in the niches (Arhiv, Konzervatorski zavod, Odjel u Splitu, Ministarstvo RH, 1928/128).

\section{Conclusion: Sternen's technique based on the methodology "conserve, do not restore"}

Sternen's approach to restoration is a link between the traditional tasks performed by an unschooled painter-restorer, and that of an educated restorer professional, with the latter approach being established in Slovenia by Professor Mirko Šubic (19001976). Sternen, according to Smrekar, restored as a painter, although according to the archive data in Split (Croatia), it is clear that he had some concept of what were in his day the modern approaches to conservation and restoration (Smrekar, 2004, 109-135; Unković, 2011, 269-276). He can thus be considered an introduction to modern conservation, thanks to his understanding (in the context of the period where he carried out his main restoration works) with regard to the preservation and presentation of the original layers. For example, Sternen felt that he should not retouch and reconstruct works if not necessary, while he always included detailed documentation of the state of the art work/monument during the restoration treatment, using the full extent of the technical capabilities of his time (even using photography). A restoration intervention, for Sternen, had to remain visible as a historical document that would show what that original was and was not, and this goal should be carried out simultaneously, to minimize the aesthetic disruption to integrity of the focal artefact. 


\section{References}

\section{Sources}

Dalmacija, akcija popravka starijih slika - restaurator M. Sternen, Arhiv: Konzervatorski zavod, Odjel u Splitu, Ministarstvo RH, 1926/45.

Informacijsko-dokumentacijski center za dediščino, Ministrstvo za kulturo RS, $1914 / 406$.

Obnova Celjskega stropa, Zgodovinski arhiv Celje, Ministrstvo za kulturo RS, SI_ ZAC/0024/002/006/00032.

Ston, sv. Mihajlo, freska, popravak fresaka - restaurator Matej Sternen, Arhiv: Konzervatorski zavod, Odjel u Splitu, Ministarstvo RH, 1926/53.

Ston, sv. Mihajlo, popravak i opis crkve, Arhiv: Konzervatorski zavod, Odjel u Splitu, Ministarstvo RH, 1928/58.

Ston, sv. Mihajlo, popravak, sredstva za popravak crkve, Arhiv: Konzervatorski zavod, Odjel u Splitu, Ministarstvo RH,1928/128.

\section{Literature}

Cevc, E., Celjski strop - mojstrovina še vedno anonimnega slikarja z začetka 17. stoletja, Acta historiae artis Slovenica 7, 2002, pp. 9-30.

Černigoj, M., Lik slovenskega konservatorja, in: Varstvo Spomenikov 10, Ljubljana 1965-66, pp. 5-38.

Đurić, V., Vizantijske freske u Jugoslaviji, Beograd 1974.

Fisković, C., Dalmatinske freske, Zagreb 1965.

Fisković, C., Ranoromaničke freske u Stonu, Prilozi povijesti umjetnosti u Dalmaciji 12, Split 1960, pp. 48-49.

Fisković, I., Romaničko slikarstvo u Hrvatskoj, Zagreb 1987.

Fisković, I., Pelješac u protopovijesti i antici, in: Pelješki zbornik 1, Zagreb 1976, pp. $15-80$.

Gabelić, S., Ciklus arhanđela u vizantijskoj umetnosti, Beograd 1991, pp. 27- 29.

Ilich-Klančnik, B., Matej Sternen (1870-1949), diplomsko delo (Master thesis), Ljubljana 1974, p. 118.

Karaman, Lj., Crkvica Sv. Mihajla kod Stona, in: Vjesnik Hrvatskog arheološkog društva 15, Zagreb 1928, pp. 81-116.

Karaman, Lj., O značenju bas-relijefa u splitskoj krstionici, Zbornik kralja Tomislava u spomen tisućugodišnjice hrvatskoga kraljevstva, Zagreb 1925, pp. 391-412. 
Kovačič, G., Celjski strop - evropska mojstrovina, Celje 2016, http://www.kamra.si/ sl/digitalne-zbirke/item/celjski-strop-evropska-mojstrovina-2.html, [1. 3. 2017].

Lupis, V. B., Sakralna baština Stona i okolice, Ston 2000, p. 57.

Mikuž, J., Matej Sternen, Retrospektivna razstava 23. 12. 1976.-13. 2. 1977, Moderna galerija Ljubljana, Ljubljana 1976, pp. 33-41.

Pahor, D., Mojstrovina še vedno anonimnega slikarja iz kroga Vredemana de Vriesa, Zbornik za umetnostno zgodovino 44, 2008, pp. 207-232.

Smrekar, A., Matej Sternen (1870-1949), Vrhniški razgledi 5, Ljubljana 2004, pp. 109135.

Srša, I., Voštani i uljni zaštitni slojevi na srednjovjekovnim zidnim slikama u Hrvatskoj, in: Portal 1 (ed. Bralić, V., Azinović Bebek, A.), Zagreb 2010, pp. 11-30.

Stele, F., Celjski strop: Umetnostno zgodovinska studija o stropu v "Stari grofiji" v Celju, Celje 1929.

Stepančić, L., France Stelè in zgodovina varstva kulturne dediščine na Slovenskem: ob stoletnici, v: Varstvo spomenikov 44, (ed. Gaspari, A., Hazler, V., Lah, L., Peskar, R., Trček Pečak, T.), Ljubljana 2014, pp. 81-104.

Štrkalj, V., Ston, crkva Sv. Mihajla, elaborat konzervatorsko-restauratorskih radova na zidnim slikama, Zagreb 1989, unpub., the pages are not numbered.

Tomas, I., Nova promišljanja o crkvi Sv. Mihajla u Stonu, Ars Adriatica 6, Zadar 2016, pp. $41-60$, p. 49.

Ujčič, A., s. v.: Šubic, Alojzij (1865-1905), Slovenska biografija, Ljubljana 2013.

Unković, I. N., O restauriranju pokretnih umjetnina u Dalmaciji pod vodstvom Ljube Karamana, Radovi Instituta Povijesti Umjetnosti 35, Zagreb 2011, pp. 269-276.

Zaninović, M., Limitacija Stonskoga polja, Adriatica praehistorica et antiqua, Zagreb 1970, pp. 489-502.

Žerovc, B., Predlog drugačne časovne umestitve nekaterih del Mateja Sternena, Zbornik za umetnostno zgodovino 46, Ljubljana 2010, pp. 123-162. 
Nina Unković

\section{Matej Sternen kot restavrator: izbrani primeri v Sloveniji in na Hrvaškem}

Ključne besede: Matej Sternen, ohranjanje stenskih poslikav, Celjski strop, cerkev Sv. Mihaela v Stonu, France Stele, Ljubo Karaman

V literaturi je Matej Sternen (1870-1949) bolje poznan kot impresionistični slikar kakor restavrator umetnin, čeprav je v svoji bogati karieri kot restavrator v letih 1898-1941 odkril in obnovil veliko umetnin, zlasti fresk v Sloveniji in Dalmaciji. Za restavratorstvo se je živo zanimal, o čemer pričajo številni izpiski o slikarski tehnologiji ter o restavratorskih in konservatorskih metodah. To je njegovo slikarstvo obogatilo tako, da se je kot slikar lotil tudi fresk in še nekaterih drugih tehnik. Bil je slikar, ki je izredno pazljivo gradil svoje slike: dobro je obvladal tehniko priprave slikarske podlage ter vedno upošteval zakonitosti barv in njihovih odnosov ter razmerij z ozirom na beli slikarski "grund «. Skupaj z bližnjima sodelavcema, umetnostnima zgodovinarjema Francetom Steletom (1886-1972) in Ljubom Karamanom (1886-1971), je Matej Sternen v svoji restavratorski praksi udejanjil v tistem času v stroki vzpostavljeno načelo »konzervirati in ne restavrirati«. Raziskava, ki temelji na terenskem delu in študiju arhivskih virov, hranjenih v Ljubljani, Celju, Splitu in Zagrebu, se osredotoča na dva pomembna spomenika umetnostne dediščine - Celjski strop in freske v cerkvici Sv. Mihaela v Stonu. Na izbranih primerih, ki sta s tehničnega in metodološkega vidika zaščite spomenikov različna, so predstavljena Sternenova strokovna izhodišča in njihova praktična realizacija $\mathrm{v}$ duhu omenjenega načela, ki zagovarja ohranjanje in zavrača agresivne restavratorske posege. 


\section{Nina Unković}

\section{Matej Sternen as a Restorer: Selected Examples in Slovenia and Croatia}

Keywords: Matej Sternen, restoration of wall paintings, Celje ceiling, Church St Michael in Ston, France Stele, Ljubo Karaman

Matej Sternen (1870-1949) is better known as an impressionist painter rather than for his restoration work, even though in his impressive career he discovered and restored a considerable number of works, especially frescos in Slovenia and Dalmatia (Croatia). His strong interest in restoration can be seen in the numerous notes he wrote about painting technologies, restoration and conservation techniques. This enriched his entire opus, as it stimulated him to try numerous painting techniques and genres, such as frescoes. Sternen was a painter who constructed his paintings very carefully, and a master in the preparation of the painting's surface, or "the ground," and always considered the laws of colours and their relationships and proportions to the white painted surface.

In his restoration practice, working together with his close colleagues the art historians France Stele (1886-1972) and Ljubo Karaman (1886-1971), Matej Sternen actualized the principle "conserve instead of restore" that was the rule in his day. This paper is based on fieldwork data and archive sources, kept in Ljubljana, Celje, Split and Zagreb, and focuses on two important monuments - the painted ceiling in the Old Manor House in Celje (Slovenia), and a wall painting in the church of St Michael in Ston (Croatia). These two cases, which are different from both technical and methodological approaches to monument protection, clearly show Sternen's professional expertise and practical realization of "conserve instead of restore," which speaks in favour of preserving the original work as opposed to aggressive restoration interventions. 